\title{
Wear and Corrosion Interactions on Titanium in Oral Environment: Literature Review
}

\author{
Júlio C. M. Souza ${ }^{1,2} \cdot$ Mariana Henriques $^{3} \cdot$ Wim Teughels $^{4} \cdot$ Pierre Ponthiaux $^{5}$ • \\ Jean-Pierre Celis ${ }^{6} \cdot$ Luis A. Rocha ${ }^{1,7}$
}

Received: 16 December 2014/Revised: 14 March 2015/ Accepted: 16 March 2015/Published online: 8 April 2015

(c) Springer International Publishing AG 2015

\begin{abstract}
The oral cavity is a complex environment where corrosive substances from dietary, human saliva, and oral biofilms may accumulate in retentive areas of dental implant systems and prostheses promoting corrosion at their surfaces. Additionally, during mastication, micromovements may occur between prosthetic joints causing a relative motion between contacting surfaces, leading to wear. Both processes (wear and corrosion) result in a biotribocorrosion system once that occurs in contact with biological tissues and fluids. This review paper is focused on the aspects related to the corrosion and wear behavior of
\end{abstract}

Júlio C. M. Souza

julio.c.m.souza@ufsc.br

1 CMEMS - Centre Microelectromechanical Systems, Department of Mechanical Engineering (DEM), Universidade do Minho, Campus Azurém, 4800-058 Guimarães, Portugal

2 School of Dentistry, Post-Graduation Program in Dentistry (PPGO), Federal University of Santa Catarina (UFSC), Campus Trindade, Florianópolis, SC 88040-900, Brazil

3 IBB - Institute for Biotechnology and Bioengineering, Centre of Biological Engineering, Universidade do Minho, 4710-057 Braga, Portugal

4 Department of Oral Health Sciences, KU Leuven, 3000 Leuven, Belgium

5 Chemical Engineering Laboratory (LGPM), Ecole Centrale Paris, 92290 Châtenay-Malabry, France

6 Department of Metallurgy and Materials Engineering (MTM), Katholieke Universiteit Leuven, 3001 Leuven, Belgium

7 IBTN/Br - Brazilian Branch of the Institute of Biomaterials, Tribocorrosion and Nanomedicine, Department of Physics, Faculdade de Ciências, UNESP - Universidade Estadual Paulista, Bauru, SP 17033-360, Brazil titanium-based structures in the oral environment. Furthermore, the clinical relevance of the oral environment is focused on the harmful effect that acidic substances and biofilms, formed in human saliva, may have on titanium surfaces. In fact, a progressive degradation of titanium by wear and corrosion (tribocorrosion) mechanisms can take place affecting the performance of titanium-based implant and prostheses. Also, the formation of wear debris and metallic ions due to the tribocorrosion phenomena can become toxic for human tissues. This review gathers knowledge from areas like materials sciences, microbiology, and dentistry contributing to a better understanding of bio-tribocorrosion processes in the oral environment.

Keywords Titanium - Bio-tribocorrosion - Wear . Corrosion · Dental implants

\section{Introduction}

Several machines, installations, and devices used in different areas can be damaged by wear and corrosion processes [1,2]. Medical devices and apparatus are also vulnerable to wear and corrosion phenomena, as reported in literature [3-6]. Most often, there is a loss of material that can lead to the deterioration of the performance of that device, machine, or installation [1]. Artificial organs, including dental implants and prostheses, possess a major drawback of a limited lifespan due to friction, wear, or decay of structural materials in the warm, humid, and corrosive environment of the human body. The simultaneous degradation of biomaterials by wear and corrosion in the oral cavity is a phenomenon that has been studied in order to prevent failures of dental restorations, implant, and prostheses, to avoid eventual detrimental effects to the 
patients, and to improve the function of oral rehabilitation systems. Therefore, the study of wear and corrosion resistance of structural materials can determine the performance of dental implants and prostheses. As a result, the reduction of restorative material loss by degradation can increase the long-term success of dental implant systems.

Tribocorrosion is a term used to describe the irreversible transformation of a material caused by a simultaneous action of chemical, mechanical (wear), and electrochemical (corrosion) interactions on surfaces subjected to a relative contact movement $[1,2,7,8]$. Thus, a corrosive environment can amplify the material loss rate by wear mechanisms as well as, inversely, wear can increase the corrosion rate $[1,9]$. The tribocorrosion rate of metallic biomaterials such as titanium depends on the mechanical and chemical properties of their oxide film as well as on the environment $[1,9,10]$. Nonetheless, titanium oxide passive film can be destroyed by bending or wear mechanisms (fatigue, abrasion, adhesive wear, fretting) exposing the underlying metal [11]. However, tribocorrosion can be beneficial in manufacturing technology like grinding and chemical-mechanical polishing of biomaterial surfaces in the fabrication of dental restorations, implants, and prostheses.

Nowadays, the tribocorrosion behavior of materials has been studied in biological environments originating the new designation of bio-tribocorrosion [3, 12-15]. Even though it is not possible to simulate the complex oral environment for biotribocorrosion tests, in vitro studies can, at least, determine the influence of each component on bio-tribocorrosion behavior of biomaterials. For instance, Guindy et al. [16] reported the failure of six dental implant systems caused by corrosion of the prosthetic superstructure. In that study, areas with clear signs of localized corrosion were detected by scanning electron microscopy on all implants and inner crown surfaces [16]. Another previous study reported a synergistic effect of distinct mechanisms, which led to total failure of implants under extrinsic common fatigue loading $[6,17]$. The propagation of a crack from the body of the retrieved implant was detected by scanning electron microscopy [6].

The tribocorrosion behavior of materials is influenced by several aspects related to contacting materials, mechanics of the tribological contact, and physico-chemical properties of the environment $[1,2]$. Mechanical aspects such as applied forces, contact geometry, and type (sliding, fretting, rolling, or impact) determine the tribocorrosion rate for a given material [1-5]. Concerning contacting surfaces, the topography (e.g., roughness, adsorbed molecules, and oxide film properties), chemical composition, and microstructure (e.g., phase distribution, grain size, etc.) of materials play an important role in the tribocorrosion system [1-5]. Finally, the corrosion of a material depends on the chemical composition, $\mathrm{pH}$, temperature, and presence of oxidative species in a gaseous or liquid environment [1].

\section{Structural Materials for Dental Prostheses and Implants}

It is important to mention that different structural materials can be used in dental implants and prostheses. For instance, commercially pure (CP) titanium is frequently used to fabricate dental implant fixtures (Fig. 1). The clinical longterm success of dental implants is related to their osseointegration $[18,19]$. Different methods are used to modify the titanium surfaces accelerating the osseointegration of dental implant fixture surfaces, such as gritblasting, acid-etching, anodization, or calcium phosphate coatings [18].

The abutment can be produced from titanium-based alloys or else from ceramic materials such as yttria partially stabilized tetragonal zirconia polycrystalline (YTZP). Abutments made of YTZP provide better results concerning esthetic for anterior restorations although data on longterm performance of fixed partial dentures on YTZP are still lacking [20, 21].

Additionally, ceramic materials are used to produce metal-free (feldspar-based porcelain fused on YTZP infrastructure) and metal-ceramic (e.g., feldspar-based ceramic fused on metallic infrastructure) crowns (Fig. 1) [22]. For a given material, a variation of properties may exist as shown in Table 1.

Such variation of properties can be explained by differences in microstructure and/or residual elements. A match of mechanical properties between materials used in implant systems is fundamental in oral rehabilitation. For instance, the wear rate of structural materials can be higher when there is a large difference in hardness between abutment and implant fixture or between abutment and crown joints. Thus, the relative importance of mechanical, physical, or chemical properties will depend on the biomaterial application. A dental implant-supported prosthesis should possess mechanical properties close to that of dental and bone structures in order to establish a long-term clinical performance and harmony with the masticatory system.

Nowadays, different dental implant-abutment joints are commercially available for implant-supported prostheses

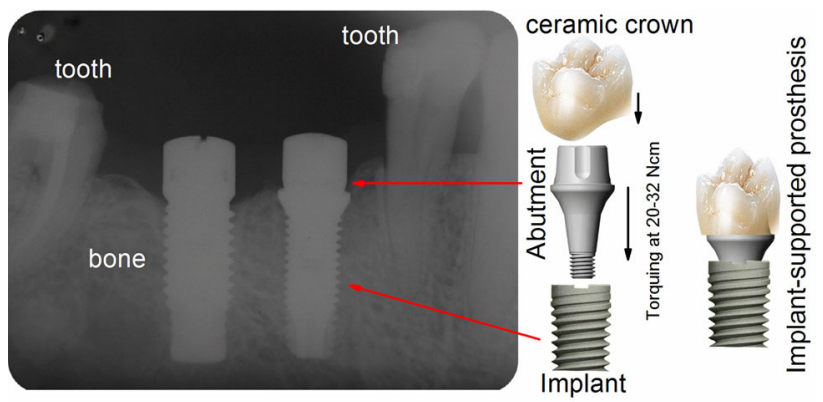

Fig. 1 Schematics of a titanium-based abutment-implant joint 
Table 1 Mechanical properties of materials used in oral rehabilitation compared to those of natural materials: enamel, dentin, and cortical bone [33-38, 122]

\begin{tabular}{llll}
\hline Materials & Tensile strength (MPa) & Elastic modulus (GPa) & Vickers hardness $(\mathrm{HV})$ \\
\hline CP Ti grade 2 $(\alpha$-titanium) & 345 & $102-119$ & $180-209$ \\
Ti-6Al-4 V $(\alpha+\beta-$-titanium $)$ & $895-930$ & $110-150$ & 350 \\
Ti-15Zr-4Nb-4Ta-0.2Pd $(\alpha+\beta$-titanium) & $715-919$ & $94-99$ & $250-350$ \\
CoCrMo & $560-690$ & $180-240$ & $317-460$ \\
Gold alloy (type IV) & $410-770$ & $95-123$ & $235-360$ \\
Dental porcelain & $34-82$ & $66-82$ & $443-780$ \\
Enamel & 10 & $75-100$ & $300-410$ \\
Dentin & 52 & $18-19$ & $80-92$ \\
Cortical bone & 140 & $10-18$ & $43-76$ \\
\hline
\end{tabular}

such as hexagon (external or internal) or Morse taper connections. In an implant-supported prosthesis, an excellent fit between titanium-based abutment and implant (Fig. 1) results in a proper mechanical integrity and distribution of masticatory forces $[23,24]$. The fit of the implant-abutment assembly is dependent on machining process and properties of the structural materials.

On the other hand, the poor fit of dental implant-based joints can result in a higher displacement of the structural parts under mastication forces or occlusal prematurity from incomplete seating [23, 24]. Binon and McHugh [23] reported on the loosening of abutment screw joint due to the implant-abutment rotational hexagonal misfit. Failures in dental implant systems have been attributed not only to biomechanical overloads but also to corrosion and wear synergy along with the cyclic loading mechanism of the masticatory process [6]. Nevertheless, it is difficult to correlate failures of dental implant systems with bio-tribocorrosion mechanisms in vivo. Therefore, corrosive substances can accumulate in the internal connection of dental implant systems and also in the biofilms formed on external and inner surfaces of the prosthetic gaps [25, 26]. The $\mathrm{pH}$ lowering associated to corrosive substances and under mechanical solicitations can decrease the long-term performance of dental implant systems $[6,13,16]$. In addition, polished surfaces can become rough in the oral cavity due to the effect of food debris or due to the friction between contacting surfaces increasing biofilm accumulation $[9,12,13]$.

\section{Mastication Forces and Distribution of Stresses Through Structural Materials}

Mastication forces produced during the chewing cycle have been described to be in the range of $10-120 \mathrm{~N}$ [27, 28]. Nevertheless, the properties of the food bolus (thickness, elastic modulus, hardness) as well as human body features (muscle activity, gender, age, weight, presence of other dental prostheses) influence the magnitude of mastication forces generated on dental surfaces [27-31]. The highest mastication forces are generated at the end of the chewing cycle when sliding motion stops as the teeth reach the centric occlusion that produces localized abrasion wear of contacting dental surfaces [27, 28]. In literature, the maximum biting forces were measured by different methods (e.g., electromyography, occlusal transducers) and are in the range of $89-150 \mathrm{~N}$ at the incisors (anterior region), $133-334 \mathrm{~N}$ at the canines, $220-445 \mathrm{~N}$ at the premolars (intermediary region), and $400-600 \mathrm{~N}$ at the molars (posterior region) [32-34].

A dental implant-supported prosthesis must present a noteworthy ability to sustain mastication forces that depend on the design and structural materials properties. The orientation of stresses is very important once axial loads promote the transfer of stress through dental implant systems to the bone tissue $[19,21]$. However, oblique loads can originate overload on structural materials and on bone tissue that can promote failures by fatigue and wear of the implant-based system [6, 24].

In addition, the presence of different materials provides abrupt variations of different properties (hardness, elastic modulus, yield strength). Also, aspects related to the design of the implants such as length, diameter, and shape can be adjusted to decrease the stress distribution to the bone [19, 36].

Computer simulations have been developed to allow evaluation of the loads distribution through dental implants systems and prostheses that could lead to material and periimplant bone loss [35-38]. Papavasiliou et al. [35] revealed, by three-dimensional finite element analysis of stress distribution around single tooth implants, that the highest stresses were concentrated in the cortical bone [35]. On axial and oblique loading at $20 \mathrm{~N}$, the highest stresses in the bone (12-16 MPa) were below the elastic limit of cortical bone (about $60 \mathrm{MPa}$ ). However, on loading at $200 \mathrm{~N}$, resolved stresses on the cortical bone were higher than that elastic limit of bone. Also, high stress values were found at the implant-abutment joint (Fig. 1) in the range of 
9 up to $18 \mathrm{MPa}$, and 110 up to $170 \mathrm{MPa}$ on oblique loading at 20 and $200 \mathrm{~N}$, respectively. However, the values were lower for axial loading at $20 \mathrm{~N}(0.5-0.9 \mathrm{MPa})$ and $200 \mathrm{~N}$ (5-9 MPa) [35]. Applying $100 \mathrm{~N}$ static axial occlusal loads, Eraslan and Inan [37] also noticed a high concentration of von Mises stresses located at loading areas of abutments and cortical bone for all models [35]. Baggi et al. [36] found numerically the highest von Mises stress values (ranging from 65 to $220 \mathrm{MPa}$ on vertical loading at $250 \mathrm{~N}$ ) at the titanium implant crest level (area between abutment and bone) that decreased for implants with large diameters [36]. Alkan et al. [38] found von Mises stress (on oblique loadings at $70 \mathrm{~N}$ ) at titanium abutment screws in the range of 80 up to $145 \mathrm{MPa}$.

As there is no periodontal ligament around implants such as in natural teeth, the shock-absorbing ability of dental implants is lower than that of natural teeth [33]. Thus, an intra-mobile element (screw thread) of titanium is often included to decrease the stress distribution to the bone $[19,35]$ although micromovements take place in the prosthetic joints [24].

\section{Electrolyte in the Oral Cavity: Human Saliva}

Human saliva consists of a mixture of fluids produced from parotid, submaxillary, and submandibular glands as well as by oral mucosal glands (labial, lingual, palatal, and vestibular glands) at a $\mathrm{pH}$ between 6 and 7 [39, 40]. The composition of saliva, which includes organic, inorganic compounds, and $99 \%$ water, is also dependent on external factors that can be present in the oral cavity [39, 41]. Surfaces inside oral cavities are regularly reached by saliva at a $\mathrm{pH}$ altered, between 3 and 8 , by external factors such as dietary, presence of acidic substances, and microbial metabolites [39, 41]. Additionally, the composition and properties of saliva can be modified by internal factors associated to salivary gland dysfunctions or to the time of the day [39, 41]. The role of saliva has been considered in the maintenance of the oral health of the human body due to the presence of numerous organic and inorganic compounds [39, 41]. Proteins (e.g., albumin, proline-rich proteins, statherin, histatin), glycoproteins (e.g., mucin), and aminoacids (e.g., leucine, glycine, glutamate, aspartate) are the main organic constituents of the saliva and valuable for microorganisms [39, 41, 42]. Even though some organic constituents are important for microbial metabolism and growth, other constituents such as antibodies (IgAs, IgM, $\mathrm{IgG}$ ) and enzymes (lyzozyme, lactoferrin, lactoperoxidase) act as regulators of microbial colonization. Additionally, carbohydrates (glucose, galactosis, and sialic acid) and lipids (phospholipids, triglycerides, and cholesterol) are also organic constituents present in the saliva.
In the oral cavity, the viscous property of the saliva provided by glycoproteins (e.g., mucin) present in the acquired pellicle can protect the dental surfaces against wear $[12,39]$. The friction recorded on titanium surfaces under sliding against an alumina ball can be reduced in the presence of water, lipids, and glycoproteins (e.g., mucin). That can be compared to the effect of commercial lubricant agents [12]. However, there are few studies on the biotribocorrosion in simulated oral environments containing glycoproteins, such as mucin and albumin both present in saliva [3, 12, 13, 15, 43, 44].

Previous studies have reported the bio-tribocorrosion behavior of titanium alloys in a buffered solution containing lypopolysaccharides (LPS) or albumin [15, 43, 44]. Khan et al. [44] revealed that the wear rate of Ti13Nb13Zr, Ti6Al7Nb, and Ti6Al4V decreased in the presence of albumin. Contrarily, Hiromoto and Mischler [43] did not find any effect of albumin on the fretting-corrosion behavior of titanium [43]. Mathew et al. [45] reported a negative effect of LPS on the corrosion/wear behavior of titanium in artificial saliva. Additionally, the presence of LPS can induce an accumulation of biofilms.

The inorganic fraction is basically represented by ions such as $\mathrm{Ca}^{2+}, \mathrm{PO}_{4}{ }^{3-}, \mathrm{Na}^{+}, \mathrm{K}^{+}$, and $\mathrm{HCO}_{3}{ }^{-}$. Bicarbonate $\left(\mathrm{HCO}_{3}{ }^{-}\right)$and phosphate $\left(\mathrm{PO}_{4}{ }^{3-}\right)$ ions act as a buffer to maintain the $\mathrm{pH}$ of the saliva between 6 and $7[39,46]$. Acting as the main buffering agent, $\mathrm{HCO}_{3}{ }^{-}$binds to $\mathrm{H}^{+}$to form $\mathrm{H}_{2} \mathrm{CO}_{3}, \mathrm{H}_{2} \mathrm{O}$, and $\mathrm{CO}_{2}$, increasing the $\mathrm{pH}$ which leads to the prevention of tooth demineralization and corrosion of dental materials [39, 41, 46]. However, the buffering mechanism can be limited by a high density of microbial cells or by a low salivary flow rate [39, 41, 46].

The salivary glands produce $1-1.5 \mathrm{~L}$ of saliva per day which is responsible for the mechanical removal of microorganisms and food stuffs. The masticatory process and the muscular movements increase the salivary output optimizing the oral cleaning [39-41, 46]. However, the salivary flow rate decreases during sleep facilitating the increase in the number of microorganisms in the oral cavity and consequently the lowering of the $\mathrm{pH}[39,41]$. In fact, the increase of lactic acid-producing bacteria metabolism is a critical factor for the lowering of the $\mathrm{pH}$.

In order to mimic human saliva, several artificial saliva solutions have been used to study the corrosion behavior of dental materials [47-49]. A previous review of nearly 60 artificial saliva recipes was carried out to clarify the role of the compounds used in the artificial saliva formulation [48]. That previous study focused on the buffer effect, the role played by $\mathrm{CO}_{2}$ gas and the presence of calcium ions, hydrogenocarbonates, hydrogenophosphates, and thiocyanates. The $\mathrm{pH}$ of the artificial saliva solutions found in literature ranged from 4.5 to $7[47,48]$. Due to the inconsistent and unstable properties of natural saliva, the 
formulation of artificial saliva solutions that react with the test material in a way similar to that of natural saliva is not easy to achieve in vitro [47, 49]. Most of the reported artificial saliva solutions are a simplified version of what may actually occur in the oral cavity in terms of solubility of components and corrosion of dental materials [47, 48].

The use of organic-free artificial saliva solutions has been often applied in corrosion studies [47-49] and tribocorrosion studies [9-13, 50, 51]. Concerning the corrosion behavior of dental materials, the properties of several artificial saliva solutions were reported in literature [47-49, 51, 52]. However, some previous studies [51, 52] reported that the corrosion behavior of dental materials in artificial saliva proposed by Fusayama [53] was most closely approximating the one in natural saliva. Nevertheless, other formulations have also been reported as most appropriate for studying corrosion of dental materials [49]. Even though the extensive number of different artificial saliva formulations is found in the literature, Fusayama's solution has been largely used to study the corrosion of dental materials including titanium and its alloys [49, 50, 54-57]. Concerning several parameters such as the use of artificial saliva, studies should be standardized in order to compare the results reported in the literature.

\section{Presence of Oral Biofilms}

Previous studies have revealed the effect of biofilm on the tribocorrosion in the oral cavity concerning the following factors: (1) biofilm composition, (2) biofilm adhesion process, (3) role of microorganisms, (4) biofilm metabolites, and (5) restorative surface characteristics. The oral cavity is a complex environment that gathers several substances from food and saliva to microorganisms and their metabolites [39]. Along time, several areas in the oral cavity can be covered by a complex microbial community embedded in an extracellular matrix composed of polysaccharides, proteins, nucleic acids, and water, known as oral biofilm [5860]. As a result, the $\mathrm{pH}$ in the oral cavity is frequently altered reaching low values after the intake of acidic substances and/or acids release from oral microbial metabolism [13, 39, 50]. Moreover, the biofilm composition is influenced by the local $\mathrm{pH}$ values, considering the release and tolerance of bacteria to acids [39, 41, 50, 61]. The temperature also varies temporarily during the intake of warm or cold foods. Therefore, there is a variation of oxygen in the oral cavity, as for example the low presence or absence of oxygen concentration in the areas below gingival margin. As a consequence, the microbial colonization in the mouth follows the variation of oxygen which promotes the preferential growth of aerobic or anaerobic microorganisms [39, 41, 62, 63]. Finally, the oral cavity habitat must not be considered as uniform since there are different micro-areas depending on the saliva composition, nutrient accumulation, tissue and restorative surfaces, and resident microorganisms [39]. The topography of dental restorative systems is of major importance for microbial colonization taking into account that rough surfaces are more susceptible to be colonized by microorganisms than smooth ones [64-68].

In the oral cavity, microbial adhesion can take place in both soft tissues and hard structures represented by tooth and restorative structures. These surfaces are usually coated with a conditioning film $(0.1-10 \mu \mathrm{m})$ (Fig. 2a) that
Fig. 2 Schematic biofilm formation and co-aggregation of multi-species biofilms (a) Initial biofilm formation by primary colonizers on a substratum covered with a conditioning film; b cell growth, division, and production of extracellular matrix (EPS); $\mathbf{c}$ coadhesion of single cells; and $\mathbf{d}$ maturation and the formation of the multispecies biofilms
A
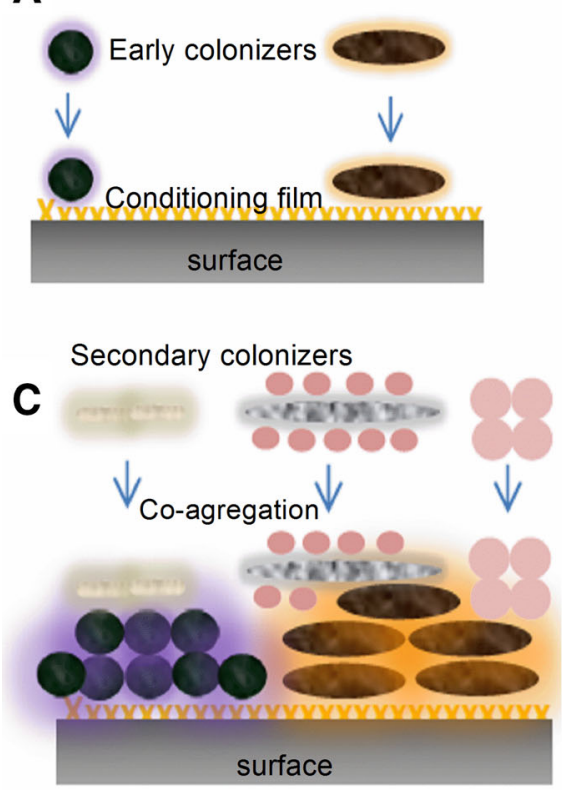

B
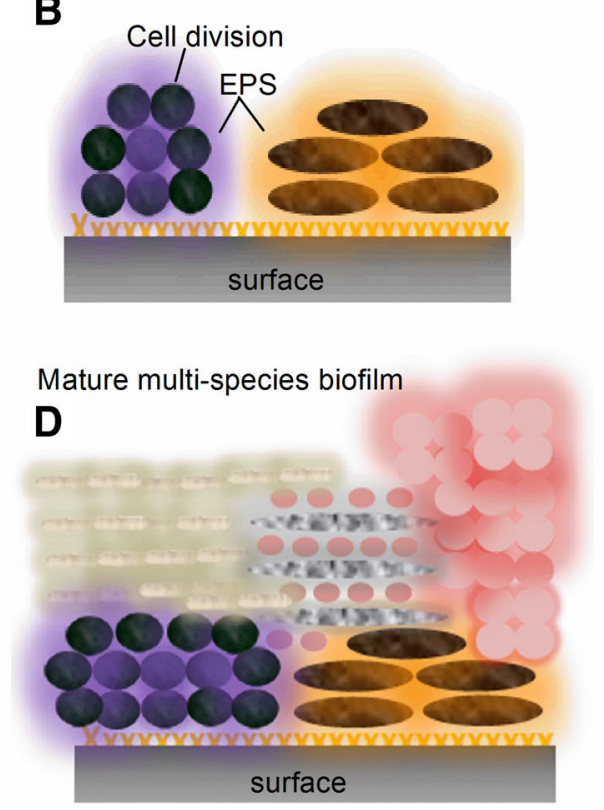
is composed of glycoproteins, ions (e.g., $\mathrm{Ca}^{2+}, \mathrm{Mg}^{2+}$ ), and water [39, 41, 69]. The conditioning film or enamel acquired pellicle, such as often known when covering tooth enamel, protects the oral surfaces against wear originated from masticatory contacts and determines the adherence of microorganisms [39, 41, 61, 67]. However, the primary microorganism colonizers present protein macromolecules on their surfaces named adhesins that bind to receptors present on glycoproteins (e.g., mucin) in the conditioning film at oral surfaces $[39,41,61,67,70]$. This is a specific mechanism of microbial colonization that allows microbial cells to bind selectively to surfaces (Fig. 2) [61, 69, 70].

Steptococcus species such as $S$. sanguinis, S. oralis, $S$. gordonii, S. mitis, S. mutans, and S. sobrinus represent $60-80 \%$ of all primary colonizers, which also include 5-30 \% species of Actinomyces naeslundii, Fusobacterium nucleatum, Capnocytophaga ochracea. Different adhesins are present in the adherence of Streptococcus species and acquired pellicle. S. sanguinis and S. oralis possess adhesins similar to lectine cellular membranes, which are called lectins. For instance, $S$. gordonii presents more than one adhesin that binds at least to three receptors, namely proline-rich proteins, salivary agglutinins, salivary amylase [39]. In order to colonize host oral surfaces, Streptococcus can use different mechanisms. At a first stage, Streptococcus mutans establishes electrostatic interactions with salivary glycoproteins receptors mediated by $\mathrm{Ca}^{2+}[39,41$, 70]. Additionally, it can occur a binding between and glycoproteins present on mucin which is part of the acquired pellicle [42, 68, 70, 71]. Moreover, these bacteria are able to produce hydrated extracellular polysaccharides (EPS), resulting from sucrose degradation by enzymes known as glycosyltransferase (GTF), as shown in Fig. 2b [39, 41]. EPS is composed of polysaccharides chains $\alpha-1,3$ and $\alpha-1,6$ glucan linkages that bind to receptors of $S$. $m u$ tans represented by GTFs, and promote the agglutination of S. mutans cells $[39,72]$. The proteoglycans and signaling molecules control the homeostatic dynamic state of the entire extracellular matrix [58].

The multilayered biomass composed of glycoproteins, water, nucleic acids, and polysaccharides chains acts as viscoelastic material which can support considerable elastic deformation under shear stresses and is able to distribute loads, thereby decreasing the contact pressure at the surface $[12,13,73-75]$. Also, that viscoelastic biomass can be responsible for the friction on oral surfaces [12].

Other microorganisms such as $S$. sanguinis, $S$. gordonii, and $S$. oralis produce EPS composed of glucans although there is a lower agglutination in these cells than in the $S$. mutans biofilm [39, 41]. Furthermore, the glycoproteins present in saliva and gingival fluid can support the coaggregation between different species like between $C$. albicans and S. mutans or among S. sanguis, S. oralis, and A. naeslundii $[39,41]$. Also, the cell-cell co-aggregation can occur by adhesin-receptor interactions [70]. Since there is a modification of the environment associated to the presence of early colonizers, secondary or late colonizers can co-aggregate with previous species forming multi-species biofilms [61, 63] as shown in Fig. 2c, d. For instance, late pathogenic colonizers such as Prevotella intermedia and Porphyromonas gingivalis can co-aggregate with filamentous (Actinomyces naeslundii) and fusiform (Fusobacterium nucleatum) bacteria that can bind to glycoproteins in the acquired pellicle or to other primary colonizers $[39,41$, $61,63]$. Finally, the cell growth and division in a complex microbial community follows nutritional and environmental conditions in the oral cavity $[61,63]$.

Leonhardt et al. [76] evaluated the early bacterial colonization on titanium, amalgam, and hydroxyapatite in vivo, and no significant quantitative and qualitative differences in bacterial colonization of these materials were found. However, Rosentritt et al. [77] reported significant differences between the $S$. mutans colonization on ceramic, composites, and alloys in vitro. These authors described that adhesion was higher on composites than on alloys which corroborates the results of Tanner et al. [71].

The microbiota present at peri-implant seems to depend on the same factors related to microbiota of natural tooth surfaces [78-83]. The highest concentration of microorganisms $(70 \%)$ is represented by Gram-positive coccus and facultative anaerobic bacillus [78]. Therefore, the commensal microbiota present in the oral cavity influences the microbial colonization of dental implant systems and prostheses [41]. For instance, Mombelli et al. [84] reported the presence of pathogens such as $P$. gingivalis, $P$. intermedia, and Fusobacterium in peri-implant microbiota of partially edentulous patients with a history of previous periodontal disease [84]. On the contrary, Danser et al. [85] did not find $P$. gingivalis in peri-implant areas of 30 edentulous patients with a history of periodontal disease. Analyzing subgingival areas of 18 unsuccessful implant systems, Alcoforado et al. [86] detected the presence of $C$. albicans on 5 implant systems, while $P$. intermedia was found only on 4 implants [86]. Rosenberg et al. [87] reported the presence of $C$. albicans in $10 \%$ of peri-implant microbiota that also comprise $P$. gingivalis, $P$. intermedia, and Fusobaterium [87]. Leonhardt et al. [76] also found the presence $C$. albicans in microbiota associated to peri-implant inflammations. These findings seem to correlate the incidence of opportunistic infections by $C$. albicans due to the use of antibiotics for peri-implant infections before the removal of implant systems [41].

In a dental implant-supported fixed prosthesis, the microbial colonization begins at prosthetic areas exposed to the oral environment taking into account that biofilm formation depends on the prosthetic design, surface 
conditions, and on the oral microbiota [41, 66, 67, 88]. After implantation, a part of the margin area of implant fixture is in contact with connective and epithelial tissues, while another part is in contact with abutment and oral fluids. In literature, a mean interfacial discrepancy of about 2.5-60 $\mu \mathrm{m}$ in implant fixture-abutment gaps was reported $[25,26,89-92]$. As the diameter of microorganisms is less than $10 \mu \mathrm{m}$, the prosthetic gaps can be effortlessly colonized by several microorganism. Hence, the penetration of microorganisms in implant internal connections can be caused by microbial leakage at the implant-abutment joints [26, 92].

Previous studies reported instability by unscrewing of about $50 \%$ of abutment screws analyzed for 1 year [93]. The presence of oral fluids and biofilms in the implant internal connection and prosthetic microgaps [12, 25, 90, 94] can be one of the factors responsible for a loss of mechanical integrity of the abutment screw by unscrewing. Thus, biofilms generated an ultra-low friction on titanium under sliding [12]. On the other hand, as a result of biofilm growth, there is a release of acidic substances from carbohydrates metabolism that alters $\mathrm{pH}$ and the oxygen content of the local environment [11]. Specifically, lactic acid-producing bacteria such as S. mutans perform fermentation of carbohydrates (e.g., sucrose) releasing lactic acid that decreases the $\mathrm{pH}$ to values lower than 5.5 and dissolves the carbonate hydroxyapatite mineral of teeth by a process called demineralization. It was also reported that $S$. mutans can promote lowering of $\mathrm{pH}$ to 4.0 , while $S$. mitis and some species of Lactobacillus promote lowering of $\mathrm{pH}$ to $4-5$ and 3.0, respectively $[41,50,93,95]$. However, the $\mathrm{pH}$ of the oral surfaces surrounding media can be lower than the ones reported that could promote a localized corrosion of titanium.

The localized corrosion of titanium caused by biofilm colonization has been revealed by previous studies [16, 56]. Mabilleau et al. [56] reported a localized corrosion of titanium in vitro after 21-day immersion in a medium containing $S$. mitis cells. Also, Souza et al. $[13,50]$ reported the decrease of corrosion resistance of titanium in the presence of $S$. mutans or $S$. mutans/C. albicans biofilms by electrochemical tests $[13,50]$. In fact, the $\mathrm{pH}$ of the medium in which biofilms grow decreased in the presence of microorganisms probably due to the release of acidic substances that reduced the corrosion resistance of $\mathrm{Ti}$ [13]. The exposure of structural materials to oral fluids, including acidic substances produced by bacterial metabolism, is associated to the corrosion of the implant fixture-abutment joint [16]. In addition, fluorides can be accumulated in biofilms depending on their structure and composition, physico-chemical properties of the solute, and biofilm thickness [96-99]. Due to the diffusion of $\mathrm{F}^{-}$ions through extracellular matrix, fluorides can also reach oral tissues and other micro-areas in the biofilm [96, 97]. The lowering of $\mathrm{pH}$ caused by the release of lactic acid from microbial metabolism in the biofilm can be responsible for a considerable concentration of HF that can corrode titanium and feldspar-based porcelain surfaces of dental implant-supported prostheses.

\section{Corrosion of Titanium}

Since the intensive work accomplished by Branemark et al. [100], titanium and its alloys have been the first-choice materials for implant systems (implant fixture, abutments) and prostheses (dental metal-ceramic crown and removable denture frameworks) in oral rehabilitation [19-21, 100].

Titanium is known as a material with a very high corrosion resistance in physiological solutions, and has an excellent biocompatibility due to the formation of a protective titanium oxide film, like $\mathrm{TiO}_{2}$, when in contact with the surrounding environment $[10,18,100,101]$. Also, properties such as low density $\left(4.5 \mathrm{~g} / \mathrm{cm}^{3}\right)$ combined with low thermal-electrical conductivity and high mechanical strength are often referred in literature and thus uphold titanium alloys as a material remarkably required in medicine and dentistry. The passive $\mathrm{TiO}_{2}$ formed on titanium surfaces is found to be amorphous. However, rutile or anatase on $\mathrm{TiO}_{2}$ films can be created, for instances, by heat treatments. Both titanium dioxide films present a tetragonal form and perform an important role upon corrosion and biocompatibility $[101,102]$. The $\mathrm{TiO}_{2}$ film possesses a high corrosion resistance in various test solutions, such as artificial saliva, Ringer's solution, $0.9 \% \mathrm{NaCl}$ solution, or physiological saline solution $[54,55]$. Nevertheless, the protective $\mathrm{TiO}_{2}$ film can degrade in the oral cavity in the presence of corrosive substances such as fluorides, lactic acid, carbamide peroxide (urea peroxide), and hydrogen peroxide [10, 54-56, 103]. The breakdown of the titanium passive film leads to a localized corrosion failure such as intergranular attack, pitting, or corrosion fatigue [101, 104].

The degradation of titanium-based surfaces at high fluoride concentrations was found in previous studies revealing the occurrence of a localized corrosion process, namely pitting corrosion $[10,55,56]$. The occurrence of pitting corrosion was described as resulting from the formation of hydrated $\mathrm{Ti}$ oxides as $\mathrm{Ti}(\mathrm{OH})_{2} \mathrm{~F}^{+}$, and salts as $\left[\mathrm{TiF}_{6}\right]^{2-}, \mathrm{TiH}_{2}, \mathrm{Na}_{3} \mathrm{Ti}_{3} \mathrm{~F}_{14}$, $\mathrm{TiF}_{4}\left[\mathrm{TiF}_{6}\right]^{3-}$ in the presence of $\mathrm{HF}[10,55]$. Such previous studies have revealed that a minimum concentration of $30 \mathrm{ppm} \mathrm{HF}$ is enough to promote a localized corrosion of titanium in fluoride solutions. In fact, the corrosion in fluoride solutions depends on the $\mathrm{pH}$ and the formation of HF produced by the dissociation of $\mathrm{NaF}$ when it is present at high concentrations, or in low $\mathrm{pH}$ solutions due to the bonding between $\mathrm{H}^{+}$and $\mathrm{F}^{-}$ions. For instance, a localized corrosion on titanium surfaces might occur in a solution containing $452.5 \mathrm{ppm} \mathrm{F}^{-}$at $\mathrm{pH} 4.2$ or in a solution containing $227 \mathrm{ppm}$ 
$\mathrm{F}^{-}$at $\mathrm{pH}$ 3.8. The formation of pits on $\mathrm{CP}$ titanium was also found in a previous study after immersing it in artificial saliva containing 11,180 [56] or $12,300 \mathrm{ppm} \mathrm{F}^{-}$[10]. Chemical analyses indicated the presence of heterogenic oxides as $\mathrm{TiOF}_{2}$ and TiOHF on CP titanium after immersing it at high

$\mathrm{F}^{-}$concentration [10].

Considering the titanium surface modification, chemical methods are useful to increase the surface roughness of dental implant fixtures in order to promote osseointegration. Such methods include etching of surfaces using acidic substances such as $\mathrm{HCl}, \mathrm{H}_{2} \mathrm{SO}_{4}, \mathrm{HNO}_{3}$, and $\mathrm{HF}$. Micro- or nano-porous surfaces can also be produced by potentiostatic or galvanostatic anodization of titanium in acidic substances $\left(\mathrm{H}_{2} \mathrm{SO}_{4}, \mathrm{HNO}_{3}, \mathrm{H}_{3} \mathrm{PO}_{4}\right.$, and $\left.\mathrm{HF}\right)$ at high current density or potential application, resulting in a thick and porous titanium oxide layer $(\sim 1 \mu \mathrm{m})$ depending on the parameters. Also, anodizing in an electrolyte-containing phosphate and calcium-based solutions can promote the formation of thick and porous layer composed of calcium and phosphates [18].

\section{Wear Processes on Dental Materials}

During chewing process, abrasion of restorative surfaces including titanium can be caused by frictional surface interactions with opposing surfaces, toothbrush and paste, food bolus, and hard particles originated from dietary [30]. A two-body abrasion has been reported when two surfaces were rubbed away from each other by direct contact with their asperities $[92,105,106]$. In the oral cavity, two-body abrasion takes place during a "non-masticatory tooth movement" [30] although it can occur in the prosthetic joint surface during masticatory tooth movement. Moreover, the presence of "intervening slurry of abrasive particles" in the tribological contact originates in the threebody abrasion [105, 106]. Under high or low stresses, this kind of mechanism occurs during the masticatory process due to the presence of abrasive particles in the food bolus $[30,31]$ or it can occur during the wear process of dental surfaces with material loss and debris formation $[9,105$, 106]. Then, abrasive particles move along the surfaces in tribological contacts scratching away the antagonist surface $[9,105,106]$. If the prosthetic joints act as a closed tribological system, the material loss will be higher than the loss in open systems where the abrasive particles move away from the tribological contact [9].

The wear phenomenon known as fatigue consists in a rupture of intermolecular bonds and a zone of subsurface damage caused by the movement of surface molecules under cyclic loads [9, 105, 106]. Consequently, there is a micro-crack formation within the subsurface oblique to the surface, which can coalesce to the surface, and thus material loss can occur [106]. Fatigue has been often associated to wear of occlusal surfaces [105]. Another wear mechanism, known as adhesive wear, occurs when, after oxide film disruption, promoting an attraction between two surfaces that are under relative contact motion. Wear particles can also be attached like platelet shapes to surfaces under friction. However, fractures of the micro-welds resulting from adhesive wear can occur and can increase the wear rate [105, 106]. Fretting is also an important wear mechanism that can occur between contacting surfaces under small-amplitude oscillatory movement [5, 43, 105, 106, 113]. The movement can result from one of the contacting members undergoing cyclic stress, and it can reduce the fatigue strength by 70-80\% [106]. Fretting wear has been associated to wear of cortical bone against titanium implant surfaces [30].

\section{Simultaneous Degradation of Titanium by Corrosion and Wear Interactions}

Friction on titanium during mastication can destroy the $\mathrm{TiO}_{2}$ film that leads to a material loss [1, 9, 13, 107] and possible failures of dental implants and prostheses [6, 17]. As a result from corrosion and wear processes, metallic ions are released, and wear particles originating from titanium were found in the surrounding tissues and associated to inflammatory reactions [106, 108-111].

Different tribocorrosion mechanisms can take place during rubbing between a ductile metal (e.g., titanium) and a hard inert counter-body (alumina), as shown in Fig. 3 [1].

Mechanical and electrochemical mechanisms are responsible for the material removal from the hard less materials (first body) during rubbing [1]. As a result, there is plastic flow with metal ejection by plowing and metal detachment forming third bodies (wear particles) [7, 8, 107]. The wear particles can be transferred and deposited on the alumina surface or spreading on the titanium surface by adhesive wear forming tribolayers [1, 9, 107]. In contact with environment, the wear particles can be oxidized and

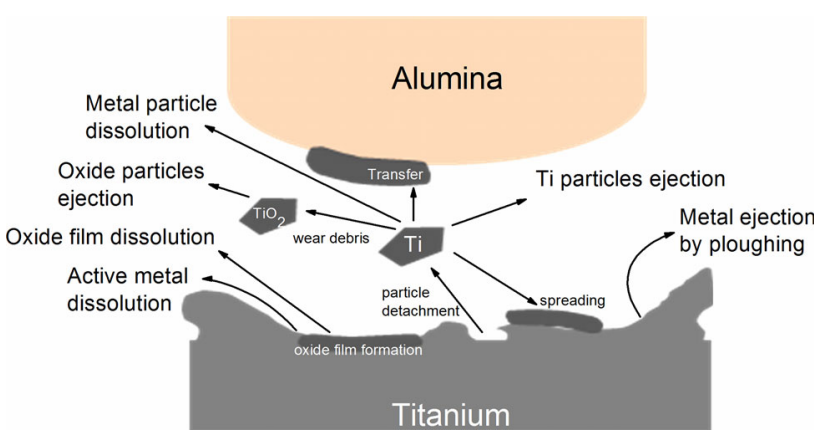

Fig. 3 Schematic tribocorrosion mechanisms of titanium. Adapted from Landolt [1] 
form solid oxide that can modify the mechanic of contact. Then, a brittle oxide particle can be formed contributing to a third-body abrasive mechanism and can extend the mechanical wear of titanium. On the other hand, a solid oxide can chemically dissolve as ions in the environment taking into account that there is also titanium dissolution and an ion release produced by electrochemical reactions between titanium and the environment [1]. The metal detachment exposes a fresh titanium surface that reacts immediately with the environment corresponding to an anodic partial current and a subsequent increase of the corrosion rate due to the high chemical reactivity of bare metal $[1,2,9,93]$. Then, a galvanic cell is established during the wear process in the electrolyte, where the bare metal (worn area) may act as an anode or a cathode, and its periphery, represented by the passive layer (unworn area), acts as a cathode or an anode, respectively $[2,9,107,112]$. Consequently, there is a current flowing between anodic and cathodic areas, which induces an electrochemical potential distribution over the surface $[2,112]$.

In fact, the chemical and mechanical properties of the titanium passive film influence the surface mechanical response of titanium as well as the third-body behavior [8$10,50]$. This comprises the repassivation rate of titanium that consists in the formation of a new $\mathrm{TiO}_{2}$ film immediately after its mechanical destruction (depassivation) $[8$, 9]. Barril et al. [113] studied the fretting corrosion of Ti6Al4V in $0.9 \% \mathrm{NaCl}$ solution and revealed a strong influence of the electrode potential on the wear rate of titanium alloys. In addition, it was revealed that the oxidation of third-body particles at anodic potentials decreases the mechanical energy involved in the wear process. Considering the presence of fluorides, the wear processes on titanium in high fluoride solutions $\left(12,300 \mathrm{ppm} \mathrm{F}^{-}\right)$are quite different compared to the ones noticed in artificial saliva without or containing up to $227 \mathrm{ppm} \mathrm{F}^{-}$. In fact, the formation of a reaction product layer on titanium at high $\mathrm{F}^{-}$concentration decreases the coefficient of friction [9]. However, a progressive corrosion of titanium has been detected by surface analysis, as well as by electrochemical measurements, indicating an active state of titanium in artificial saliva at high $\mathrm{F}^{-}$concentration. The wear rate of titanium in sliding contacts was too fast at high fluoride concentration which could occur in titanium-based structures used in prostheses and dental implants. This last case could be a cause for failures of titanium-based implant systems considering that the material loss can increase microgaps in the prosthetic joints and modify the contact area of structural materials. As a consequence, the distribution of loads on the implants could be altered promoting over-loads at certain contact areas. Additionally, over-loads can increase the wear rate of prosthetic materials exposed to relative contact motions.
In the presence of biofilms, tribocorrosion tests revealed a low friction on titanium covered with biofilms $[12,13]$. The properties of the biofilms were similar to those of the lubricant agents used to decrease the wear rate of materials $[12,13]$. However, the lowering of $\mathrm{pH}$ promoted by microbial species negatively affected the corrosion resistance of titanium surfaces [12,13]. A wear-corrosion process that takes place during sliding of titanium-based contacting surfaces in a corrosive environment can be a cause of failure in dental implant-supported systems. In dental implant systems, the lower friction in sliding contacts could cause a loss of mechanical integrity of internal connections.

\section{Interaction of Wear Debris with Surrounding Tissues}

In the case of medical implants and prostheses, wear debris and ions release produced due to the loss of material by bio-tribocorrosion of prosthetic surfaces have been related to tissue inflammatory reactions [108-111, 114]. Additionally, some studies revealed a highly significant relationship between the amount of peri-implant inflammation and the magnitude of alveolar bone loss surrounding implants $[110,111]$ that can be faster than that surrounding natural tooth due to the absence of inflammatory cellular response provided from periodontal ligament [41].

The presence of metallic ions and particles in human tissues induces the activation of macrophages, neutrophils, and T-lymphocytes with elevation of cytokines and metallic proteinases that can promote bone resorption [115-117]. Coalescence of particles of all classes (including titanium particles) originating from prostheses was often seen in the vesicles of macrophage cytoplasm in the liver $(0.1-10 \mu \mathrm{m}$ in diameter), spleen, and para-aortic lymph nodes [117-120]. In the lymph nodes, titanium particles ranged from $0.1 \mu \mathrm{m}$ up to $50 \mu \mathrm{m}$, while in the liver and spleen the particles ranged from $10 \mu \mathrm{m}$ [119]. Hallab et al. [121] investigated the binding of metals such as $\mathrm{Ti}, \mathrm{Co}, \mathrm{Cr}, \mathrm{Al}$ (originating from implant wear and corrosion) to serum proteins that can mediate immune reactions [120]. Even though the long-term biologic effect of circulating metals is not completely known, it could be determined by the detection and characterization of these metal-protein complexes [120]. After wear tests of titanium alloys in vitro, Okazaki et al. [122] verified a low cellular growth in mediums containing $\mathrm{Al}$ and $\mathrm{V}$ compared to that in free- $\mathrm{Al}$ and free- $\mathrm{V}$ mediums. This indicates a potential cytotoxic effect of $\mathrm{Al}$ and $\mathrm{V}$ for human cells.

A significant release of $\mathrm{Ti}^{-}, \mathrm{Al}-$, and $\mathrm{V}$-ions has been reported in previous studies [10]. Literature data have revealed the release of $\mathrm{Al}$ - and $\mathrm{V}$-ions caused by passive 
film dissolution, though those alloying elements confer good mechanical properties to Ti-alloys. A corrosion of metallic materials has been classified in three classes based on the ion release [109]: (Class I) $10 \mu \mathrm{g} / \mathrm{cm}^{2}$ week or less; (Class II) $10-100 \mu \mathrm{g} / \mathrm{cm}^{2}$ week or less; (Class III) $100-1000 \mu \mathrm{g} / \mathrm{cm}^{2}$ week. Based on Manaranche and Hornberger's [109] study, alloys of class III could stimulate an adverse biological response in patients due the high release of ions. In that respect, CP titanium and Ti6Al4V alloy could induce adverse biological reactions when in contact with high fluoride concentrations [10, 108, 109]. The release of aluminum ions may, however, be considered as a toxic element, while vanadium ions as a mutagenic agent [109].

An association between ultrafine $\mathrm{TiO}_{2} \quad\left(\mathrm{UF}^{-\mathrm{TiO}_{2}}\right)$ $(<100 \mathrm{~nm}$ in diameter) particles and adverse biologic effect has been reported in the literature [94, 108]. Garabrant et al. [94] reported that $50 \%$ of titanium metal production workers exposed to $\mathrm{TiO}_{2}$ particles suffered from respiratory symptoms, followed by injury of pulmonary function [121]. In agreement with previous studies in rats [123, 120, 124], recent studies in cultured human cells have also shown genotoxicity and cytotoxicity effects of UF-TiO [109]. However, the precise pathways of chromosomal changes, apoptosis formation, and inhibition of cell division by $\mathrm{UF}^{-\mathrm{TiO}_{2}}$ are unclear [109]. These findings led us to consider the possible adverse biological effect of $\mathrm{TiO}_{2}$ particles $(<100 \mathrm{~nm}$ in diameter) produced during bio-tribocorrosion mechanisms of titanium in the human body.

\section{References}

1. Landolt D (2006) Electrochemical and materials aspects of tribocorrosion systems. J Phys D 39:3121-3127

2. Ponthiaux P, Wenger F, Drees D, Celis JP (2004) Electrochemical techniques for studying tribocorrosion processes. Wear 256:459-468

3. Yan Y, Neville A, Dowson D (2006) Biotribocorrosion-an appraisal of the time dependence of wear and corrosion interactions: I. The role of corrosion. J Phys D 39:3200-3205

4. Gilbert JL, Sivan S, Liu Y, Kocagöz SB, Arnholt CM, Kurtz SM (2015) Direct in vivo inflammatory cell-induced corrosion of CoCrMo alloy orthopedic implant surfaces. J Biomed Mater Res A 103A:211-223

5. Brown S, Kawalec J, Merritt K, Montague A, Payer J (1996) Effects of material combination, surface treatment, and environment on fretting-corrosion of Ti6Al4V. In: Brown SA, Lemons JE, Medical applications of titanium and its alloys: the material and biological issues. ASTM STP 12726

6. Manda MG, Psyllaki PP, Tsipas DN, Koidis PT (2009) Clinical device-related article observations on an in-vivo failure of a titanium dental implant/abutment screw system: a case report. J Biomed Mater Res B 89B:264-273

7. Mischler S, Rosset E, Stachowiak GW, Landolt D (1993) Wear 167:101

8. Mischler S, Spiegel A, Stemp M, Landolt D (2001) Wear 251:1295-1307
9. Souza JCM, Barbosa SL, Ariza E, Celis J-P, Rocha LA (2012) Simultaneous degradation by corrosion and wear of titanium in artificial saliva containing fluorides. Wear 292:82-88

10. Souza JCM, Barbosa SL, Ariza E, Ponthiaux P, Henriques M, Teughels W, Celis J-P, Rocha LA (2015) How do titanium and Ti6Al4V corrode in fluoridated medium as found in the oral cavity? An in vitro study. J Mater Sci Eng C 47:384-393

11. McMillin CR (1996) Mechanical breakdown in the biological enviroment. In: Ratner HA (ed) Biomaterials science: an introduction to materials in medicine. Academic Press, San Diego, pp 267-271

12. Souza JCM, Henriques M, Oliveira R, Teuhels W, Rocha LA, Celis J-P (2010) Biofilms inducing ultra-low friction on titanium. J Dent Res 89(12):1470-1475

13. Souza JCM, Henriques M, Oliveira R, Teuhels W, Celis J-P, Rocha LA (2010) Do oral biofilms influence the biotribocorrosion behavior of titanium? Biofouling 26(4):471-478

14. Felgueiras HP, Castanheira L, Changotade S, Poirier F, Oughlis S, Henriques M, Chakar C, Naaman N, Younes R, Migonney V, Celis J-P, Ponthiaux P, Rocha LA, Lutomski D (2014) Biotribocorrosion (tribo-electrochemical) characterization of anodized titanium biomaterial containing calcium and phosphorus before and after osteoblastic cell culture. J Biomed Mater Res B. doi:10.1002/jbm.b.33236

15. Runa MJ, Mathew MT, Fernandes MH, Rocha LA (2014) First insight on the impact of an osteoblastic layer on the bio-tribocorrosion performance of Ti6Al4 V hip implants. Acta Biomater $14: 483-488$

16. Guindy JS, Schiel H, Schmidli F, Wirz J (2004) Corrosion at the marginal gap of implant-supported suprastructures and implant failure. Int J Oral Maxillofac Implants 19:826-831

17. Tagger Green N, Machtei EE, Horwitz J, Peled M (2002) Fracture of dental implants: literature review and report of a case. Implant Dent 11:137-143

18. Hanawa T (2011) A comprehensive review of techniques for biofuntionalization of titanium. J Periodontal Implant Sci 41:263-272

19. Misch CE (2005) Dental implant prosthetics. Mosby, St Louis

20. Guess PC, Att W, Strub JR (2012) Zirconia in fixed implant prosthodontics. Clin Implant Dent Relat Res 14(5):633-717

21. Rinke S (2015) Anterior all-ceramic superstructures: chance or risk? Quintessence Int 46(3):217-718

22. Kimmich M, Stappert CF (2013) Intraoral treatment of veneering porcelain chipping of fixed dental restorations: a review and clinical application. J Am Dent Assoc 144(1):31-44

23. Binon P, McHugh MJ (1996) The effect of eliminating implant/ abutment rotational misfit on screw joint stability. Int J Prosthodont 9:511-519

24. Gratton DG, Aquilino SA, Stanford CM (2001) Micromotion and dynamic fatigue properties of the dental implant-abutment interface. J Prosthet Dent 85:47-52

25. Quirynen M, van Steenberghe D (1993) Bacterial colonization of the internal part of two-stage implants. An in vivo study. Clin Oral Implant Res 4:158-161

26. Quirynen M, Bollen CML, Eyssen H, van Steenberghe D (1994) Microbial penetration along the implant components of the Brånemark system ${ }^{\circledR}$. An in vitro study. Clin Oral Implants Res 5(4):239-244

27. De Gee AJ, Pallav P (1994) Occlusal wear simulation with the ACTA wear machine. J Dent 22:S21-S27

28. Schindler HJ, Stengel E, Spiess WE (1998) Feedback control during mastication of solid food textures-a clinical-experimental study. J Prosthet Dent 80:330-336

29. Kohyama K, Sasaki T, Hayakawa F (2008) Characterization of food physical properties by the mastication parameters measured by electromyography of the jaw-closing muscles and mandibular 
kinematics in young adults. Biosci Biotechnol Biochem 72:1690-1695

30. Lambrechts P, Debels E, Landuyt V, Peumans M, Meerbeek BV (2006) How to simulate wear? Overview of existing methods. Dent Mater 22:693-701

31. Lambrechts P, Goovaerts K, Bharadwaj D, De Munck J, Bergmans L, Peumans M, Van Meerbeek B (2006) Degradation of tooth structure and restorative materials: a review. Wear 261:980-986

32. Proeschel PA, Morneburg T (2002) Task-dependence of activity/bite-force relations and its impact on estimation of chewing force from. J Dent Res 81:464

33. Anusavice (2005) Philip's science of dental materials. Elsevier, Philadelphia

34. Sevimay M, Usumez A, Eskitascioglu G (1999) the influence of various occlusal materials on stresses. Transferred to implantsupported prostheses and supporting. Bone: a three-dimensional finite-element study. J Biomed Mater Res B 73:140-147

35. Papavasiliou G, Kamposiora P, Bayne SC, Felton DA (1996) Three-dimensional finite element analysis of stress-distribution around single tooth implants as a function of bony support, prosthesis type, and loading during function. Prosthet Dent 76:633-640

36. Baggi L, Cappelloni I, Di Girolamo M, Maceri F, Vairo G (2008) The influence of implant diameter and length on stress distribution of osseointegrated implants related to crestal bone geometry: a three-dimensional finite element analysis. J Prosthet Dent 100:422-431

37. Eraslan O, İnan O (2009) The effect of thread design on stress distribution in a solid screw implant: a 3D finite element analysis. Clin Oral Invest 14(4):411-416

38. Alkan I, Sertgo A, Ekici B (2004) Influence of occlusal forces on stress distribution in preloaded dental implant screws. J Prosthet Dent 91:319-325

39. Marsh PD, Martin MV (1999) Oral microbiology, 4th edn. Butterworth-Heineman, London

40. Dodds MWJ, Johnson DA, Yeh C-K (2005) Health benefits of saliva: a review. J Dent 33:223-233

41. De Lorenzo JL (2004) Microbiologia para o estudante de Microbiologia. Atheneu, São Paulo

42. Ge J, Catt DM, Gregory RL (2004) Streptococcus mutans a-enolase binds salivary mucin MG2 and human plasminogen. Infect Immun 72:6748-6752

43. Hiromoto S, Mischler S (2006) The influence of proteins on the fretting-corrosion behaviour of a Ti6Al4 V alloy. Wear 261:1002-1011

44. Khan MA, Williams RL, Williams DF (1999) The corrosion behaviour of Ti6Al4 V, Ti6Al4Nb and Ti13Nb13Zr in protein solutions. Biomaterials 20:631-637

45. Mathew MT, Barão VA, Yuan JC, Assunção WG, Sukotjo C, Wimmer MA (2012) What is the role of lipopolysaccharide on the tribocorrosive behavior of titanium? J Mech Behav Biomed Mater 8:71-85

46. Bardow A, Moe D, Nyvad B, Nauntofte B (2000) The buffer capacity and buffer systems of human whole saliva measured without loss of CO2. Arch Oral Biol 45:1-12

47. Leung VW-H, Darvell BW (1997) Artificial saliva for in vitro studies of dental materials. J Dent 25:475-484

48. Gal J-Y, Fovet Y, Adib-Yadzi M (2001) About a synthetic saliva for in vitro studies. Talanta 53:1103-1115

49. Duffó GS, Castillo EQ (2004) Development of an artificial saliva solution for studying the corrosion behavior of dental alloys. Corrosion 60:594-602

50. Souza JCM, Ponthiaux P, Henriques M, Oliveira R, Teughels W, Celis J-P, Rocha LA (2013) Corrosion behaviour of titanium in the presence of Streptococcus mutans. J Dent 41:528-534
51. Holland RI (1992) Corrosion testing by potentiodynamic polarization in various electrolytes. Dent Mater 8:241-245

52. Marek M (1983) The corrosion of dental materials. Treat Mater Sci Technol 23:331-394

53. Fusayama T, Katayori T, Nomoto S (1963) Corrosion of gold and amalgam placed in contact with each other. J Dent Res 42:1183-1197

54. Schiff N, Gosgpgeat B, Lissac M, Dalard (2002) Influence of fluoride content and $\mathrm{pH}$ on the corrosion resistance of titanium and its alloys. Biomaterials 23:1995-2002

55. Nakagawa M, Matsuya S, Shiraishi T, Ohta M (1999) Effect of fluoride concentration and $\mathrm{pH}$ on corrosion behavior of titanium for dental use. J Dent Res 78:1568-1572

56. Mabilleau G, Bourdon S, Joly-Guilou ML, Filmon R, Baslé MF, Chappard (2006) Influence of fluoride, hydrogen peroxide and lactic acid on the corrosion resistance of commercially pure titanium. Acta Biomater 2:121-129

57. Robin A, Meirelis JP (2007) Influence of fluoride concentration and $\mathrm{pH}$ on corrosion behavior of Ti-6Al-4 $\mathrm{V}$ and Ti-23Ta alloys in artificial saliva. Mater Corros 58:173-180

58. Meredith JE, Fazeli B, Schwartz MA (1993) The extracellular matrix as a cell survival factor. Mol Biol Cell 4:953-961

59. Jiang X, Pace JL (2006) Microbial biofilms. In: Rupp M, Pace JL (eds) Biofilms, infections and antimicrobial therapy. Taylor \& Francis, Boca Ranton, pp 3-19

60. Costerton JW, Stewart PS, Greenberg EP (1999) Bacterial biofilms: a common cause of persistent infections. Science 284:1318-1322

61. Rickard AH, Gilbert P, High NJ, Kolenbrander PE, Handley PS (2003) Bacterial coaggregation: an integral process in the development of multi-species biofilms. Trends Microbiol 11:94-100

62. Sissons CH, Wong L, Shu M (1998) Factors affecting the resting $\mathrm{pH}$ of in vitro human microcosm dental plaque and Streptococcus mutans biofilms. Arch Oral Biol 43:93-102

63. Kolenbrander PE, London J (1992) Ecological significance of coaggregation among oral bacteria. Adv Microbiol Ecol $12: 183-217$

64. Barbour ME, O'Sullivan DJ, Jenkinson HF, Jagger DC (2007) The effects of polishing methods on surface morphology, roughness and bacterial colonisation of titanium abutments. J Mater Sci 18(7):1439-1447

65. Quirynen M, Bollen CML (1995) The influence of surface roughness and surface free energy on supra and subgingival plaque formation in man. J Clin Periodont 22:1-14

66. Quirynen M, De Soete M, Van Steenberg D (2002) Infections risk for oral implants: a review of literarture. Clin Oral Implant Res 13:1-19

67. Teughels W, Van Assche N, Sliepen I, Quirynen M (2006) Effect of material characteristics and/or surface topography on biofilm development. Clin Oral Implant Res 17:68-81

68. Li M, Yang S, Wang Z (2001) The influence of surface roughness on bacteria adhesion on titanium. Chin J Stom 36:431-433

69. Gibbons RJ (1989) Bacterial adhesion to oral tissues: a model for infectious diseases. J Dent Res 68:750-760

70. Busscher HJ, van der Mei HC (1997) Physico-chemical interactions in initial microbial adhesion and relevance for biofilm formation. Adv Dent Res 11:24-32

71. Tanner J, Vallittu PK, Söderling E (2000) Adherence of Streptococus mutans to an E-glass fiber-reinforced composite and conventional restorative materials used in prosthetic dentistry. J Biomed Mater Res 49:250-256

72. Shimamura A, Nakano YJ, Mukasa H, Kuramisu HK (1994) Identification of amino acid residues in Streptococcus mutans glucosyltransferases influencing the structure of the glucan product. J Bacteriol 176:4845-4850 
73. Vinogradov AM, Winston M, Rupp CJ, Stoodley P (2004) Rheology of biofilms formed from the dental plaque pathogen Streptococcus mutans. Biofilms 1:49-56

74. Cense AW, Peeters EAG, Gottenbos B, Baaijens FPT, Nuij AM, van Dongen MEH (2006) Mechanical properties and failure of Streptococcus mutans biofilms, studied using a microindentation device. J Microbiol Method 67:463-472

75. Celli J, Gregor B, Turner B, Afdhal NH, Bansil R, Erramilli S (2005) Viscoelastic properties and dynamics of porcine gastric mucin. Biomacromol 6:1329-1333

76. Leonhardt A, Olsson J, Dahlen G (1995) Bacterial colonization on titanium, hydroxyapatite, and amalgam surfaces in vivo. J Dent Res 74:1607

77. Rosentritt M, Hahnel S, Gröger G, Mühlfriedel B, Bürgers R, Handel G (2007) Adhesion of Streptococcus mutans to various dental materials in a laminar flow chamber system. J Biomed Mater Res B 86:36-44

78. Mombelli A, Mericske-Stern R (1990) Microbiological features of stable osseointegrated implants used as abutments for overdentures. Clin Oral Implant Res 1:1-7

79. Nakou M, Mixx FHM, Oosterwald PJM, Kruijsen JCVM (1987) Early microbial colonization of premucosal implants in edentulous patients. J Dent Res 66:145-151

80. Palmisano DA, Mayo JA, Block MS, Lancaster DM (1991) Subgengival bacteria associated with hydroxyapatite-coated dental implants: morphotypes and trypsin-like activity. Int J Oral Maxilofac Implants 6:313-318

81. Hultin M, Boström L, Gustafsson A (1998) Neutrophil response and microbiological findings around teeth and dental impants. J Periodontol 69:1413-1418

82. Gatewood RR, Cobb CM, Killoy WJ (1993) Microbial colonization on natural tooth structure compared with smooth and plasma-sprayed dental implant surfaces. Clini Oral Implant Res 4:53-64

83. Quirynen M, Listgarten M (1990) The distribution of bacterial morphotypes around natural teeth and titanium implants ad modum Branemark. Clin Oral Implant 1:8-13

84. Mombelli A, Marxer M, Gaberthuel T, Grunder U, Lang NP (1995) The microbiota of osseointegrated implants in patients with story of periodontoal disease. J Clin Periodontol 22:124-130

85. Danser M, Van Winkelhoff AJ, Van Der Velden U (1997) Periodontal bacteria colonizing oral mucous membranes in edentulous patients wearing dental implants. J Periodontol 68:209-216

86. Alcoforado GAP, Rams TE, Feik D, Slots J (1991) Aspects bacteriologiques des implants dentaires osteointegrés chez l'homme. J Parodontol 10:11-18

87. Rosenberg M et al (1991) Microbial differences in 2 clinically distinct types of failures of osseointregrated implants. Clin Oral Implant Res 2:135-144

88. Mombelli A (2002) Microbiology and antimicrobial therapy of peri-implantitis. Periodontol 2000(28):177-189

89. Scarano A, Assenza B, Piattelli M, Iezzi G, Leghissa GC, Quaranta A, Tortora P, Piattelli A (2005) A 16-year study of the microgap between 272 human titanium implants and their abutments. J Oral Implant 31:269-275

90. Piatelly A, Scarano A, Paolantonio M, Assenza B, Leghissa GC, Di Bonaventura G, Catamo G, Piccolomini R (2001) Fluids and microbial penetration in the internal part of cement-retained versus screw-retained implant-abutment connections. J Periodontol 72:1146-1150

91. Do Nascimento C, Barbosa RES, Issa JPM, Watanabe E, Ito IY, Albuquerque RF Jr (2008) Bacterial leakage along the implantabutment interface of premachined or cast components. Int $\mathbf{J}$ Oral Maxillofac Surg 37:177-180
92. Tsaryk R, Kalbacova M, Hempel U, Scharnweber D, Unger RE, Dieter P, Kirkpatrick CJ, Peters K (2007) Response of endothelial cells to oxidative stress on Ti6Al4 V alloy. Biomaterials 28:806-813

93. Jemt T, Pettersson P (1993) A 3-year follow-up study on single implant treatment. J Dent 21:203-208

94. Garabrant DH, Fine LJ, Oliver C, Bernstein L, Peters JM (1987) Abnormalities of pulmonary function and pleural disease among titanium metal production workers. Scand J Work Environ Health 13:47-51

95. Van Houte J, Sansone C, Joshipura K, Kent R (1991) In vitro acidogenic potential and mutans streptococci of human smooth surface plaque associated with initial caries lesions and sound enamel. J Dent Res 70:1503-1507

96. Watson PS, Pontefract HA, Devine DA, Shore RC, Nattress BR (2005) Penetration of fluoride into natural plaque biofilms. J Dent Res 84:451-455

97. Ekstrand J, Oliveby A (1999) Fluoride in the oral environment. Acta Odontol Scand 57:330-333

98. Duckworth RM, Jones Y, Nicholson J, Jacobson APM, Chestnutt IG (1994) Studies on plaque fluoride after use of F-containing dentifrices. Adv Dent Res 8:202-207

99. Tatevossian A (1990) Fluoride in dental plaque and its effects. J Dent Res 69:645-652

100. Branemark PI, Zarb GA, Albrektsson (1987) Tissue integrated prostheses: osseointegration in clinical dentistry. Quintessence Publishing Co., Chicago

101. Shreir LL, Jarman RA, Burstein GT (2000) Corrosion testing, monitoring and inspection. Corrosion. Butterworth-Heinemann, Oxford

102. Kruger J (2003) Passivity. ASM handbook, corrosion: fundamentals, testing, and protection, vol 13A. ASM International, New York, pp 61-67

103. Oshida Y, Sellers CB, Mirza K, Farzin-Nia F (2005) Corrosion of dental metallic materials by dental treatment agents. Mater Sci Eng 25:243-348

104. Covino BS Jr, Cramer SD (2003) Introduction to forms of corrosion. ASM handbook, Corrosion: fundamentals, testing, and protection, vol 13A. ASM International, New York, p 189

105. Mair LH (2000) Wear in the mouth: the tribological dimension. In: Addy EA (ed) Tooth wear and sensitivity. Clinical advances in restorative dentistry. Martin Dunitz, London

106. Neale MJ (2001) The tribology handbook. Butterworth-Heinemann, Oxford

107. Vieira AC, Ribeiro AR, Rocha LA, Celis JP (2006) Influence of $\mathrm{pH}$ and corrosion inhibitors on the tribocorrosion of titanium in artificial saliva. Wear 261:994-1001

108. Wang JJ, Sanderson BJS, Wang H (2007) Cyto- and genotoxicity of ultrafine $\mathrm{TiO}_{2}$ particles in cultured human lymphoblastoid cells. Mutat Res 628:99-106

109. Manaranche C, Hornberger H (2007) A proposal for the classification of dental alloys according to their resistance to corrosion. Dent Mater 23:1428-1437

110. Broggini N, McManus LM, Hermann JS, Medina R, Schenk RK, Buser D, Cochran DL (2006) Peri-implant inflammation defined by the implant-abutment interface. J Dent Res 85:473-478

111. Broggini N, McManus LM, Hermann JS, Medina RU, Oates TW, Schenk RK, Buser D, Mellonig JT, Cochran DL (2003) Persistent acute inflammation at the implant-abutment interface. J Dent Res 82:232

112. Mallia B, Dearnley PA (2007) The corrosion-wear response of Cr-Ti coatings. Wear 263:679-690

113. Barril S, MischlerS Landolt D (2005) Electrochemical effects on the fretting corrosion behaviour of Ti6Al4 V in $0.9 \%$ sodium chloride solution. Wear 259:282-291 
114. Buscher R, Tager G, Dudzinski W, Gleising B, Wimmer MA, Fischer A (2005) J Biomed Mater Res B 72B:206

115. Haynes DR, Rogers SD, Hay S et al (1993) The differences in toxicity and release of bone-resorbing mediators induced by titanium and cobalt-chromium wear particles. J Bone Joint Surg A 75:825-834

116. Maloney WJ, Lane Smith R, Castro F, Schurman D (1993) Fibroblast response to metallic debris in vitro. J Bone Joint Surg A 75:835-844

117. Kumazawa R, Watari F, Takashi N, Tanimura Y, Uo M, Totsuka $\mathrm{Y}$ (2002) Effects of Ti ions and particles on neutrophil function and morphology. Biomaterials 23:3757-3764

118. Case CP, Langkamer VG, James C, Palmer MR, Kemp AJ, Heap PF, Solomon L (1994) Widespread dissemination of metal debris from implants. J Bone Joint Surg B 76:701-712

119. Urban RM, Jacobs JJ, Tomlinson MJ, Gavrilovic J, Black J, Peoc'h M (2000) Dissemination of wear particles to the liver, spleen, and abdominal lymph nodes of patients with hip or knee replacement. J Bone Joint Surg Am 82:457

120. Goodman SB (2007) Wear particles, periprosthetic osteolysis and the immune system. Biomaterials 28:5044-5048

121. Hallab NJ, Jacobs JJ, Skipor A, Black J, Mikecz K, Galante JO (2000) Systemic metal-protein binding associated with total joint replacement arthroplasty. J Biomed Mater Res 49:353-361

122. Ozakaki Y (2001) A New Ti-15Zr-4Nb-4Ta alloy for medical applications. Curr Opin Sol St Mater Sci 5:45-53

123. Afaq F, Abidi P, Matin R, Rahman Q (1998) Cytotoxicity, prooxidant effects and antioxidant depletion in rat lung alveolar macrophages exposed to ultrafine titanium dioxide. J Appl Toxicol 18:307-312

124. Baggs RB, Ferin J, Oberdorster G (1997) Regression of pulmonary lesions produced by inhaled titanium dioxide in rats. Vet Pathol 34:592-597 